\title{
Media Studies and New Media Studies
}

\author{
Sean Cubitt
}

\section{History and Geography}

Media studies lies at a crossroads between several disciplines, as reflected in the multiple names of academic departments dealing in media. This typically undisciplined discipline arose in a concatenation, still unresolved, of scholars from several traditions in the humanities and social sciences - ethnographers of everyday life, US and European communications scholars, interpersonal and commercial communications specialists, literary scholars, sociologists of subcultures - and today includes a range of activities whose approaches include economics and political economy, regulation, technology, textual analysis, aesthetics, and audience studies. There is no single canon of defining theoretical works, and only a loose assumption as to which media are to be studied, often defined by institutional matters: which media are studied may be circumscribed by the existence of journalism, pubishing, photography, or music schools claiming title to those media forms, as more frequently art history, literary, and linguistic studies bracket off their specific media formations. By media studies we presume the study of the technical media as they have arisen since the nineteenth century, in four broad categories: print, recording, broadcasting, and telecommunications. Given the typical shapes of neighboring disciplines studying specific media such as literature and music, a common concentration has been on industry, governance, and audience, with a specific address to aesthetics only in the case of the technical media. A specific change then for new media studies has been that the genres and business models once regarded as proper to each of these categories have, with the rise of digital media, converged aesthetically and economically. This has not posed a significant challenge to most of the schools of enquiry that have grown up over the past century that have taken technical media as their focus. In fact, the hybrid origins of the field of study have tended to produce a surprisingly holistic sense of mission: to understand media we need to understand their materiality as objects and systems,

A Companion to New Media Dynamics, First Edition. Edited by John Hartley, Jean Burgess, and Axel Bruns. (C) 2013 Blackwell Publishing Ltd. Published 2013 by Blackwell Publishing Ltd. 
as economies and polities, in their operations in the social, cultural, economic, and political lives of the people whose thoughts and passions they mediate. Though we are constrained to use the phrase, few media studies researchers care for the expression "the impact of media on ...": mediation is the material form in which we exchange wealth, exercise power, and reproduce our species. The convergence of previously somewhat discrete media and corporations might be understood as creating the possibility of thinking this way about media; or we might believe that the idea of universal mediation is common to both phenomena, and perhaps an aspect of our stage of social evolution. Either way, the holistic approach is by now integral to media studies' confrontation with and assimilation into new media.

Discussions of new media must include some definition of the new. In media studies, that newness can be given a practical date: October 13, 1993, the date of the release of the Mosaic web browser, which opened up network computing for the mass participation of the later 1990s and the new century. Other dates might work as cleanly - the personal computer revolution of the 1980s, perhaps - but do not entail the common-sense awareness that emerged in the ensuing months that something massive and life-changing had begun. Prior phases, as far as mainstream media studies is concerned, constitute a prehistory of the popular or mass uptake (depending on the school of thought involved) that turned laboratory or experimental formats into technical media of the scale and significance of the press or television. $1993 \mathrm{can}$, then, serve as the watershed of the new in media studies.

Statements of this kind are controversial, not only because other competing dates might serve but also because media historiography is a central and hotly debated aspect of media studies. Among the most cited texts in the field, Walter Benjamin's "Work of Art" essay $(1969,2003)$ and Marshall McLuhan's Understanding Media (1964) both established periodization as a major feature of media studies, the former distinguishing handcraft from mechanical; the latter distinguishing oral, alphabetic, print, and electronic media as distinct epochs of human history. While McLuhan's ostensible technological determinism has been warmly debated ever since, the fundamental notion that the history of media is important to understanding contemporary media formations has become doctrinal. Political historians intersect with communications specialists in key works in the British tradition of Thompson (1963), Williams (1958, 1961), and Anderson (1983), and rather differently in key works the European tradition such as Mattelart $(1994,1996,2000)$ and Debray $(1996,2000,2004)$. A significant reorientation of these analytical studies has come in the wake of digitization (though not specifically because of it) in the form of media archeology, an approach to historiography that takes as its problem the origins of the contemporary. Leading figures Lisa Gitelman (1999, 2006), Oliver Grau (2003), Erkki Huhtamo (2005, 2006), Jussi Parikka (2007, 2012), Jonathan Sterne (2003), Siegfried Zielinski (1999, 2006), and perhaps the best-known exponent, Friedrich Kittler $(1997,1999,2010)$, differ in many respects but share a passion for meticulous scholarship, a readiness to understand technical detail, an openness to long durations, and a sense of the contingency of media evolution that learns from 
but cuts across the orientation to progress that characterized McLuhan's work. The arrival of new media brought about a serious reconsideration of the mathematical as well as engineering bases of computing, and a fascination with ostensibly marginal media that, however, have had important reverberations in contemporary media: technologies as varied as spirographs (Huhtamo 2007) and filing systems (Vismann, 2008).

In many instances, media archeology points toward continuities between earlier and contemporary forms of media, based on specific discoveries in visual perception (e.g., the phi-effect, previously thought of as persistence of vision) or the physics of light (lens design from Galileo to Zeiss Ikon). Relatively few media archeologists also attend to the structure of the industries involved in developing, standardizing, and disseminating media innovations (although film historians provide a counter example: see Crafton 1997; Gomery 2005). But, while individual, often national, industries have received significant attention, the lack of archeological enquiry into the histories of regulatory instruments and institutions has been a significant lacuna, one that has begun to weigh on more recent attempts to theorize the interplay of influences in the formation of emergent media forms among engineers, corporations, governments, and international agencies such as the International Telecommunications Union. As a result, important critical insights into the evolution and changing capabilities and orientations of such bodies have received less attention than have the technologies they serve to constrain and regulate (see MacLean 2003 for an example of how such historical research can inform present policy). Since one of the most imposing results of new media dynamics has been the increasingly rapid globalization of communications infrastructures, and increasing dependence on them for economic, political, social, and cultural globalizations, the lack of work historicizing the new terrain of global media governance is a specific weakness in contemporary media studies, albeit one that is being addressed, if tangentially, in the context of significant new work on Internet and telecommunications governance in the international field (Chakravartty and Sarikakis 2006; Goldsmith and Wu 2008; deNardis 2009; Collins 2010).

The relative poverty of institutional histories can perhaps be explained by a double phenomenon coinciding with the emergence of new media networks in the 1990s. Under the influence of postmodern critique, the thesis that history was becoming a cipher encouraged a new spatial emphasis in media analysis. Meanwhile, the acceleration of both global flows and everyday life tended to reduce the felt importance of time, and to replace it with (often troubled) new orientations to space and place. The most influential study of these phenomena remains the three-volume The Information Age by Manuel Castells (2000 [1996], 2004 [1997], 2000 [1998]). Building on foundations of substantial empirical research, Castells conceptualized the network as the central form of globalization in the late twentieth century. Drawing on world systems theory but challenging theorists for whom the decline of the nation state as a political force and the fixed relation of core to periphery were doctrine, Castells - along with other leaders in the geographical turn such as 
David Harvey (1989) and Saskia Sassen (1991, 1994) - emphasized the space-time compression of the new media landscape, the rise of flexible accumulation in postFordist, informationalized industries, and the cosmopolitanism of corporate elites, in a world in which access to the speed of networks connected such elites from city to city, bypassing both rural and industrial hinterlands and the urban poor. While the point had been made theoretically before (e.g., by Virilio 1986), the mass of data supporting the hypothesis deepened the theory by opening up new insights into the different modes in which place (e.g., Augé 1995) and time (e.g., Hassan 2003) are experienced in the global network. The geographical turn also coincided with the rise of postcolonial challenges to entrenched cultural studies analyses, which knocked on into media studies. De-Westernizing media studies (Curran and Park 2000) became a significant project in its own right, not least as new media began to shift from their early US/European biases toward, among other factors, a stage at which English was no longer the dominant or even the majority language of the Internet. Older theories of media imperialism continued to be voiced, especially by North American activists such as Chomsky (2003) and McChesney (2008), but more sophisticated accounts of media experience, informed by research into migration and diaspora, began to offer less paranoid, but in certain senses even more uncomfortable, accounts (e.g., Thussu 1998, 2000). David Morley's work $(2000,2007)$ and his collaboration with Kevin Robins (1995; see also Robins 2007) are exemplary of these enriched dialogues with, for example, the complex constructions of home that aggregate around not only technological devices (the mobile phone, the home page) but also the imagination of "home" among migrants and nationals afraid of their arrival. As a number of researchers have established, migration no longer means being severed from the life of the home culture: live news, music and film downloads, and VOIP (voice over Internet protocol) calls can keep migrants as close to their cultures of origin as they wish, even as migration offers economic options and sometimes cultural freedoms that may not be available where they grew up.

In the 1980s, in a first inkling that such issues might become major political arenas, the European Union published the green paper "Television Without Frontiers" (Commission of the European Communities 1984), whose title played on a popular Eurovision coproduction. The document was based on the arrival of satellite television, one of the first electronic technologies to entirely ignore the nature of state boundaries. Early radio treaties had allowed small nations such as Luxembourg to broadcast to their neighbors; there was always at least an implicit if not explicit agreement to permit some infringement of what was regarded as a domain of territorial sovereignty. The role of the International Telecommunication Union (ITU) here explains some of the subsequent anomalies: broadcast wavebands were a scarce resource, needed for emergency services and defense as well as news and entertainment. They were legitimate matters for intergovernmental address. However, with the vastly increased spectrum availability brought about by satellite and digital technologies, the ostensibly natural monopolies of governments over spectrum ceased to hold water. The ITU's state-based structure, however, did not 
allow it to evolve into the kind of global instrument of governance that would be required by the organically growing and exponentially expanding Internet of the early 1990s (O'Siochrú et al. 2002). A number of ad hoc groups took over critical areas such as the domain name system (Mueller 2004), effectively laying claim to a functioning Habermasian public sphere of enlightened engineers devoted to "rough consensus and running code" (Froomkin 2003). By the time of the UN-organized World Summit on the Information Society in 2005, at the lowest count 15 bodies claimed jurisdiction over different, often overlapping, aspects of Internet governance, and many more laid claim to a stake in particular aspects from indigenous rights to censorship. The central concern - whether nations could still stake a claim to sovereignty over "their" media - remains one of the most contentious in media policy circles. As we will see below, recent developments in media studies point toward a dialectical solution to the apparent impasse, suggesting that we are beyond the period of emergence and are now already reorienting political struggle and economic competition toward the new terrain, neither state nor market, of the network.

\section{Political Aesthetics}

Immediately prior to the launch of the World Wide Web and overlapping with its early years, the dominant discourse was interactivity, and the characteristic media CD-ROM and - discursively if not in actuality - immersive virtual reality. During the 1990s, the new buzzword was connectivity, a term whose meaning was to change in connotation in the 2000s, when it was increasingly allied to discourses of creativity, user-generated content, and crowd-sourcing. The rise of apps toward the end of the 2000s signaled a major return to interactivity, which had never gone away but had been pretty much corralled in the games arena during the previous decade. The new e-readers of the 2009-2010 season already featured interactionrich content, especially for younger users, signaling a return to the style of the CD-ROM, which had been gradually sidelined during the heady rush toward the Internet as the primum mobile of contemporary media. The period also saw the rise of an increasingly digital cinema. Disney Studios' Tron (1982) had for the most part used analog devices to depict a digital virtual world; 1992's Lawnmower Man featured several minutes of rather lurid computer-generated imagery (CGI) and a script that centered on the network capability of computing. One decade on, with Harry Potter and the Chamber of Secrets, The Lord of the Rings: The Two Towers, Men in Black II, Spiderman, and Star Wars: Episode II - Attack of the Clones slugging it out for the top box-office slot, scarcely a frame of any event movie was free of digital attention, from special effects to nonlinear video editing to digital grading. Meanwhile, the typical media for recording and playing back content had moved from analog magnetic tape to digital optical systems, and in the music business to MP3 files. 
The move from physical objects to screen displays and speakers directly driven by software has lead in two directions: toward a comparative analog-digital aesthetics, especially in specialist discourse on recorded media, and toward a political economy of "immateriality." The discourse on digital aesthetics began early in photography, where commentators were quick to point out the malleability of digital images and the severance of an older belief in the veracity and verisimilitude of the photographic image (Ritchin 1990; Wombell 1991; Mitchell 1992). The realist paradigm, which focused on the privileged relation between the photographic image and the situation it depicted, was perhaps stronger among photography critics than in film studies, where decades of semiotics had placed the relation between image and scene deeply in doubt. All the more curious, then, that in the 2000s very similar concerns began to be voiced among cinema scholars, in their most sophisticated expression in D.N. Rodowick's The Virtual Life of Film (2007). The discussion is marred by a lack of understanding concerning the operation of light-reactive chipsets in comparison with the older photo-mechanical processes. Here photographers have a stronger background, the technical aspects of photography being integral to its analysis in ways that are rarely the case in film studies. The equivalent complaint in musicology is, however, rare: popular discourse concerns fidelity and response of different formats, and their currency rather than their distinctive forms. Jonathan Sterne's work on music file formats $(2006,2012)$ is a welcome innovation in its articulation of the importance of compression-decompression algorithms (codecs), an issue scarcely raised in audiovisual media (but see Mackenzie 2008).

The issue of immateriality has been voiced most assertively in the political economy of Italian postautonomist thought (Lazzarato 1996) but has received specific attention in relation to labor in the media and software industries, in particular from scholars such as Terranova (2006). The concept derives once again from a binary opposition between analog and digital, this time, however, in terms of products and production. Where the economics of Fordism concentrated on the production of physical goods, the move to brands and intangibles such as TV shows or celebrities in the post-Fordist economy produced artifacts that have no physical form. Instead, the "mere" physical goods - sneakers, or indeed computers and mobile phones - are manufactured in sweatshop conditions because there is no longer major profit to derive from manufacture: the source of wealth is the immaterial good represented by the Nike swoosh or Apple's logo and characteristic Jonathan Ives designs. The immaterialization of labor does lead to a characteristic legal form that has become a major topic in new media studies: intellectual property. Unlike material goods, where the legal definition of privation applies (private property is distinguished by conferring the right to deny use to another; theft as depriving the owner), intellectual or immaterial goods are not privative; that is, I can have an idea, give it to you, and still have it myself. Creating a new property regime (ostensibly by extending and toughening historic provisions for copyright and patent law) is a constitutive aspect of the business models that have developed to exploit new media since 1993 . We will return to them below. 
Closely aligned with the immaterial labor thesis is the thesis of affective labor, which proposes that much of the highly geared production of the creative industries is designed not to meet needs but to articulate with flows of desire and sensual or emotional connectivity (Massumi 2002). Between Marx on one side and Deleuze and Guattari on the other, the affective turn points beyond the digital toward what Patricia Ticineto Clough (2008) calls "biomediated" subjectivity. The emphasis on affect distinguishes instinctual and preindividual formations from the subjectively experienced, socialized emotions, seeing in them the promise of a new form of sociality and subjectivity while at the same time, again in Clough's analysis, seeing them as prone to being recruited to biopolitical management in the form, for example, of the racist expression of cultural anxieties. On the one hand, this has led to celebrations of user-generated content as a new democratization of culture in the figure of the "produser" (Bruns 2008). On the other, observations of the clustering of like-minded communities and their capacity for withdrawing from public debate (Sunstein 2007) and critiques of the exploitation of freely given labor have opened the field of affective labor to new forms of political debate (Scholz and Liu 2011).

The phrase "biopolitical" points to the third major influence on the new media studies of the last decade: a return to the work of Michel Foucault, but this time to the late work on governmentality and specifically on the transitions from disciplinary to biopolitical rule. The former, it will be recalled, had as its icon Bentham's panopticon, the prison run from a central tower through whose windows all inmates could be surveyed at any time while the guard remained invisible, thus promulgating a habit of acting as if under constant surveillance, internalizing the disciplinary codes of the institution. Such a vision of surveillant government informed important early studies of the surveillance society (Gandy 1993; Lyon 1994) and remained important in the increasingly sophisticated turn to analysis of the imbrication of commerce in contemporary surveillance (Elmer 2004; Lyon 2007). This characterization fit a particular dystopian account of cyberspace in the 1990s and early 2000s, countering the heady boosterism characteristic of Wired magazine. In some respects, it can be read as a remnant of the distrust, even hatred, of the "military-industrial complex" that fired the late 1960s counter-culture, that same counter-culture that, as Fred Turner (2006) argues, was also responsible for the development of the free-wheeling but ultimately military-industrial culture of Silicon Valley.

This binary of surveillant disciplinary rule and the metaphor of cyberspace as postnational frontier and libertarian sanctuary (Barlow 1996) gave out, however, in the first great crisis to affect the new medium: the dot-com crash of 2001. After a bubble of overinvestment in vaporware, fostered by the belief that business models imported from pre-Internet media would build fortunes, the NASDAQ's plunge from its March 2000 peak of 5132.52 points seemed to provide a fitting conclusion to the first wild period of homesteading the open prairies of the Internet. But entrepreneurs were swift to learn lessons from the handful of companies that survived the crash. While AOL Time Warner, which had used a combination of 
retail mall and magazine business models, took substantial losses, three firms came through smelling of roses: Amazon, eBay, and Google. All three were net-native, all three had built their businesses and their customer bases in the online arena using online techniques, and all three were pioneers of social media. The dot-com crash was instrumental in focusing business attention on social media - Web 2.0 - as the way to monetize what the web was best at: connectivity. While some early start-ups such as FriendFinder and MySpace have subsequently lost their major market position, other portals such as Facebook, Flickr, Twitter, and YouTube have thrived. Meanwhile, retailers such as Amazon and more recently iTunes have embraced the potential of social networks to tailor word-of-mouth recommendations to customers in the guise of communities of taste and interest, and Google has perfected the art of inviting users to participate in improving their services in hundreds of ways, from donating features to Google apps to folksonomies, which provide metatags for material that eludes standard word searches, such as music, images, and video.

This leads us to one of the key media studies problematics of the 2000s. In 1977, Dallas Smythe (1994) opined that the economics of advertising depended on the unpaid work of paying attention that audiences provided to TV stations, who on-sold to advertisers. In the case of the Internet, not only do users pay attention and not only do they (like TV audiences) pay for the devices required to do so, but they also often, indeed increasingly, produce the content that attracts the attention and so the advertising revenue. Even if the theses of immaterial and affective labor are incorrect, the accusation remains that the Internet presents itself as a playground but is in effect a factory for the production of playful activities that then become intellectual property of portal owners, or provide unpaid content on which advertisers batten, or both.

The extent to which this constitutes a market is disputed. While Marxist scholars (informed by systems theory and other contemporary intellectual trends) such as Christian Fuchs (2008) maintain that this is the most recent form of capitalist exploitation, others see it as the precursor of a new kind of economy. In an early version of the theory, Richard Barbrook (1998) suggested that the Internet economy was a hybrid affair, one side still tied to the old capitalist economy, the other an emergent gift economy. This premise became a highly practical platform for software developers in the free-libre open-source software (FLOSS) movement, as canonized in the work of Richard Stallman (2002), and has been more broadly promulgated by the peer-to-peer ( $\mathrm{P} 2 \mathrm{P})$ movement, especially through the instigator of the $\mathrm{P} 2 \mathrm{P}$ Foundation, Michel Bauwens (see e.g. Bauwens 2005). Bauwens' fundamental thesis is that the gift economy works. In instances such as Linux and Wikipedia, to take the best known, a single user might donate ten hours of work and in return receive the fruits of thousands, even hundreds of thousands, of hours in return. The principle has been adapted for real-world projects such as the design of an environmentally viable car (the open-source or OScar), microloan concepts adapted from Grameen Bank's pioneer development economics, and Kickstarter (a site on which creatives and others post projects and invite visitors to invest small sums with small or purely symbolic returns). Bauwens, an indefatigable conferencier and 
public advocate, freely admits that bricks-and-mortar businesses still require capital investment but looks forward to the gradual replacement of the banking system with a more personal and networked economics of reciprocity. Bauwens - and others, notably the late green radical André Gorz (2010) and the Oekonux community (www.oekonux.org) - may be regarded as representing the radical end of a spectrum that also includes such luminaries of the liberal tradition as Lessig $(2004,2006)$, von Hippel (2005), and Benkler (2006). At the most conservative end of the spectrum, von Hippel proposes an extension of the prosumer principle, according to which businesses and consumers both stand to gain when the consumer takes over the final elements of production, such as tailoring kitchen designs for just-in-time manufacture, assembling an automobile design from a menu of options, or installing software and other custom features on a new computer. This principle, von Hippel argues, should be extended to user-generated content online, including software development and other creative conceptual (or "immaterial") labor. Benkler sees this process as vital to the renewal of capital. Together with Lessig, he has been a major voice in campaigns against the increasingly rigidity with which intellectual property laws have been legislated and applied in national and international fora. They have been instrumental in establishing Creative Commons, a more propertyoriented license than Stallman's General Public License (GPL) (www.fsf.org), which allows authors to retain some rights over their productions.

The debates over intellectual property have been extremely heated in part because they implicate not only economic benefits but also principles of socialization and polity, especially what has been dubbed the hacker ethic (Levy 1984; Himanen 2001): the principle that access to information should be unlimited and total. The principle clashes not only with principles of private property but also with professional media ethics - notably in the case of WikiLeaks - and with the principles of centralized authority. In the early period of Internet communications, a favored metaphor was the rhizome, a thesis mooted in 1980 by the French philosophers Deleuze and Guattari (1980). The typical form of authority, they argued, was tree-like: a single organism rooted to its own place. Rhizomatic organization linked hundreds of quasi-autonomous organisms into a single interdependent complex assemblage. Allied with the metaphors of the nomad - for whom territory was not about occupying position but trajectories - and of smooth space (permitting flows) versus striated, hierarchized, static spaces, the rhizome offered a vivid image for the fluidity and interconnected network experience of the early web. However, already by the mid-1990s, Critical Art Ensemble (1994) had begun to observe that innovative forms of capitalist corporate culture had already begun to employ exactly these characteristics in the interests of what David Harvey (1989) would describe as "flexible accumulation."

In the same Italian intellectual milieu that brought the ideas of Marx, Deleuze, and Foucault together, the conditions of employment so determined were described in a term that has become critical to new activist politics and to the media analysis of new media formations: precarity. The history of the term is usefully traced by Raunig (2010). In a first iteration, precarity referred to the status of factory workers 
threatened with the sack, and was extended to include the reserve army of labor for whom Marx had reserved the damning term Lumpenproletariat: migrants, the homeless, illegals, and the gray economy. Swiftly, however, the original themes of precarious labor and precarious social conditions were perceived as a victimology, suggesting a passive class without resources to struggle. In a significant revaluation associated with the politics of not working and the exit from capital, precariousness or precarity was seen instead as a productive state of autonomy from capital. The idea was rapidly assimilated into the already-existing hacker culture as well as the bohemian underworld of European and increasingly also American cities, of both North and South. Precarity was seen as the condition that permitted people to hold down a paying job temporarily so that they could invest their real time and energies into code-hacking, creative arts, community-building, and any other autonomous activity designed for pleasure or communion rather than profit (Berardi 2009, n.d.).

\section{The Study of New Media Practice}

The critical ethnography that David Morley (1980) launched in relation to television audiences rapidly met older traditions: the subcultural sociology of Becker's Outsiders (1966) and the anthropology of institutions (from Alvarado and Buscombe 1978 to Born 2005). Sociology of both online and computer-based subcultures drew on many of the base techniques of earlier sociologists and anthropologists. Pioneering works by Kidder (1981) on software engineers and Turkle (1984) on nascent geek culture paved the way for a determined ethnography of the Internet pioneered by the founders of the Association of Internet Researchers (e.g., Jones 1999). Because fans took to the Internet like ducks to water, early studies of fan literature (e.g., Vermorel and Vermorel 1989, based on letters sent to David Bowie and others) were supplemented by studies based on easy access to vast archives of online interactions, stories, art, and conversations. These openings have powered extensive literature in online ethnography, a new practice based largely on textual (and to a lesser extent visual and auditory) materials shared in fan communities. An unusual quality of this kind of ethnography is that the researcher may never meet the people studied, bringing a host of challenges to the truth-claims of older ethnographic practices where emotional cues, for example, were visibly and audibly integral to the meeting. Much of the analysis of audiences is therefore still based on textual aesthetics and interpretation.

Games studies' accounts of "audience" have especially broken free of the training early researchers gained in film studies, first through the "ludology" debates of the 1990s (Aarseth 1997) and now due to the rich mixture of traditions flourishing today (Wolf and Perron 2003; Perron and Wolf 2009). A number of influential, mainly US, texts address the cultural forms of new media (Bolter and Grusin 1999; Manovich 2001; Jenkins 2008), with Jenkins especially asserting the power of the 
active audience to create meanings and cultures, more so now that digital tools enable both making and sharing of cultural artifacts. A more innovative line of enquiry is associated with Silverstone and Hirsch's (1992) investigation into the meanings and uses of domestic technologies. In many respects these studies, which also drew on design history and the then-emergent field of science and technology studies, opened the way for some of the most important sociological investigations, including both games and software studies. An important aspect of Silverstone and Hirsch's work, and of Morley's continuing research, is the articulation of these cultural aspects of consumption with the reorganization of labor in the digital economy. This is a significant advance on an older formation in media studies that, like cultural studies, eschewed analysis of the workplace as a communicative and cultural environment. Early analysts noted, on the one hand, the transformation of the workplace and the proletarianization of office work (Braverman 1974), and, on the other, the failure of new media to provide, alone, the efficiencies they were expected to, as workers learned to subvert workplace computers for entertainment and other personal purposes (Sproull and Kiesler 1991). Analyses of the media (e.g., Tufte 2006) and cultures of the digital workplace such as Knorr-Cetina and Brügger's (2002) study of the finance industry indicate a continuing growth in concern with workplace media as well as entertainment and news functions.

The mediation of work in the twenty-first century is difficult to separate from changes in the mediation of power. The reduction of political life to biopolitical population management is not necessarily efficient, as suggested by hung parliaments in Britain and Australia, gridlocked Presidential-Congressional relations in the USA, and the suspension of the Canadian parliament. The political event - in the sense of a history-changing action - seems increasingly rare in political life (Badiou 2006); and, as the authors of a recent activist text argue, the problem with Badiou's events is that they all seem to be in the past (Papadopoulos et al. 2008). As Jodi Dean (2009) has argued, all that we appear to have gained from Web 2.0 is the obligation to Twitter. We feel no similar duty to listen and respond. That attitude is magnified and refined in the case of politicians, she argues: the phrase "I hear you" uttered by a President or Prime Minister is code for "I must allow you your right to free speech but I have no intention whatever of paying attention to your point of view." It is for this reason that activist networks have become so important to new media studies: unlike finance workers, activists constantly debate why and how they operate, including the nature of the software they operate in (Kelty 2008).

This extends to the most recently emerging trend in new media studies: ecocritical accounts of the materials, production, energy use, and recycling of digital hardware. Such studies address, for example, the notorious dependency of the mobile phone industries on coltan extracted by child labor from war-ravaged Eastern Congo, with consequent habitat destruction and the threatened species loss of the iconic mountain gorilla (Hayes and Burge 2003). Others look at the environmental and health impacts of semiconductor manufacture (Holden and Kelty 2005) and at the energy signature of cloud computing (Cubitt et al. 2010), while a great deal of work 
has followed the Basel Action Network $(2002,2005)$ in engaging with both consumer generation of e-waste (Grossman 2007) and the specifics of labor in the processing of toxic residues (Maxwell and Miller 2008; Feilhauer and Zehle 2009). Indications are that strategic minerals are already in too short supply for current rates of growth to continue; and debates over whether technical solutions or austerity measures are the better response will be vivid.

The ethical, political, economic, and environmental futures of network communications and new media more generally are, then, in flux. Struggle for governance will be exacerbated by the accelerating "Internet of things" and ubiquitous computing; the digital divide will continue to grow, even though access to low-level equipment and skills is increasing in the developing world and among the homeless in the wealthy regions. Environmentalism is unlikely to have a purchase in the normative politics of gridlock: not when the top ten companies in the Fortune 500 are exclusively in the petroleum and automobile sectors, only in 2010 joined by finance companies who benefit from consumer debt associated with homes, cars, and of course computers. Demands to integrate "emergent markets" into the global economy will keep human labor cheaper than cleaner automated recycling and ensure that technical standardization will be increasingly important. In this area, the success of the QWERTY keyboard layout is instructive: responsible for the epidemic of forearm injuries among computer users, the standard was developed to slow typists by placing letters in a less efficient order, yet 140 years later it still dominates. Efficiency and elegance do not secure standardization, which rests on the interplay between economics, politics, and cultural inertia. At the same time, while monopolies such as those of IBM, Microsoft, and now Google and Facebook will continue to mark the rapidly evolving media scene, the mass participation of users in the new media indicates that not all battles are lost. A history of user-generated innovation also points toward the opposite conclusion: that corporations and governments have constantly to keep up with grassroots network communications innovation, and that the political economy of intellectual property rights and exclusion no longer fit the new conditions. We can expect to see amplified in the near future two major fields of dispute: open-source and universal service. The first is already under attack in debates over the implementation of HTML5 and IP version 6, while the second is most clearly exposed in the use of industrial and political espionage in major cyber-attacks on US defense contractors and military personnel apparently originating in China. The network is no longer emergent - it is the terrain on which a grand battle is being fought between three forces: the nation state, re-emergent in the form of the new economies of the BRICK countries (Brazil, Russia, India, China, Korea); the market, now firmly dominated by intellectual property rights; and the net-native forces of both profit-based corporations such as Google and nonprofit communities such as Linux. The shape of the new net-natives will evolve through a period of intense pressure to ensure that the claims of both older formations are heard. Thus, we may stand on the brink of extraordinary proliferations of creative interaction (Gauntlett 2011) or we may be faced with increasing monopolization 
(as in key software markets) and political control (as in China's Golden Shield policy). It is unlikely that new media studies will be lacking in matters to discuss, or a public purpose for its deliberations.

\section{References}

Aarseth, E. (1997) Cybertext: Perspectives on Ergodic Literature. Baltimore, MD: Johns Hopkins University Press.

Alvarado, M. and Buscombe, E. (1978) Hazell: The Making of a Television Series. London: BFI.

Anderson, B. (1983) Imagined Communities: Reflections on the Origin and Spread of Nationalism. London: Verso.

Augé, M. (1995) Non-Places: Introduction to an Anthropology of Supermodernity, trans. J. Howe. London: Verso.

Badiou, A. (2006) Being and Event, trans. O. Feltham. New York: Continuum.

Barbrook, R. (1998) “The Internet Gift Economy.” First Monday. http://firstmonday.org /htbin/cgiwrap/bin/ojs/index.php/fm/article/view/1517/1432.

Barlow, J.P. (1996) “A Declaration of the Independence of Cyberspace.” https://projects .eff.org/ barlow/Declaration-Final.html.

Basel Action Network (2002) Exporting Harm: The High-Tech Trashing of Asia. www.ban .org/E-waste/technotrashfinalcomp.pdf.

Basel Action Network (2005) The Digital Dump: Exporting High-Tech Re-use and Abuse to Africa. www.ban.org/BANreports/10-24-05/index.htm.

Bauwens, M. (2005) "The Political Economy of Peer Production." C-Theory. www.ctheory .net/articles.aspx?id=499.

Becker, H. S (1966) Outsiders: Studies in the Sociology of Deviance. New York: Macmillan.

Benjamin, W. (1969) "The Work of Art in the Age of Mechanical Reproduction" in H. Arendt, ed., Illuminations, trans. H. Zohn. New York: Schocken, pp. 217-251.

Benjamin, W. (2003) "The Work of Art in the Age of its Technological Reproducibility: Third Version" in H. Eiland and M.W. Jennings, eds., Selected Writings, vol. 4: 1938-1940. Cambridge, MA: Bellknap Press/Harvard University Press, pp. 251-283.

Benkler, Y. (2006) The Wealth of Networks: How Social Production Transforms Markets and Freedom. New Haven, CT: Yale University Press.

Berardi, F. ("Bifo") (2009) Precarious Rhapsody: Semiocapitalism and the Pathologies of the Post-Alpha Generation, trans. A. Bove, E. Empson, M. Goddard, et al. London: Minor Compositions.

Berardi, F. ("Bifo") (n.d.) "Info-Labour and Precarisation," trans. E. Empson. www .generation-online.org/t/tinfolabour.htm.

Bolter, J.D. and Grusin, R. (1999) Remediation: Understanding New Media. Cambridge, MA: MIT Press.

Born, G. (2005) Uncertain Vision: Birt, Dyke and the Reinvention of the BBC. London: Vintage. Braverman, H. (1974) Labour and Monopoly Capital: The Degradation of Work in the Twentieth Century. New York: Monthly Review Press.

Bruns, A. (2008) Blogs, Wikipedia, Second Life, and Beyond: From Production to Produsage. New York: Peter Lang. 
Castells, M. (2000 [1996]) The Rise of the Network Society, The Information Age: Economy, Society and Culture Vol. I. Cambridge, MA; Oxford, UK: Blackwell.

Castells, M. (2004 [1997]) The Power of Identity, The Information Age: Economy, Society and Culture Vol. II. Cambridge, MA; Oxford, UK: Blackwell.

Castells, M. (2000 [1998]) End of Millennium, The Information Age: Economy, Society and Culture Vol. III. Cambridge, MA; Oxford, UK: Blackwell.

Castells, M. (1998) The Information Age: Economy, Society and Culture volume 3: End of Millenium. Oxford: Blackwell.

Chakravartty, P. and Sarikakis, K. (2006) Media Policy and Globalization. Edinburgh: Edinburgh University Press.

Chomsky, N. (2003) Media Control: The Spectacular Achievements of Propaganda, 2nd edn, New York: Open Media.

Clough, P.T. (2008) “The Affective Turn: Political Economy, Biomedia and Bodies". Theory Culture Society 1(25), 1-22.

Collins, R. (2010) Three Myths of Internet Governance. Bristol: Intellect.

Commission of the European Communities (1984) Television Without Frontiers, COM (84) 300 Final. Brussels: CEC.

Crafton, D. (1997) The Talkies: American Cinema's Transition to Sound. Berkeley, CA: University of California Press.

Critical Art Ensemble (1994) The Electronic Disturbance. Brooklyn, NY: Autonomedia.

Cubitt, S., Hassan, R., and Volkmer, I. (2010) "Does Cloud Computing Have a Silver Lining?" Media Culture \& Society, 32(2), 149-158.

Curran, J. and Park, M.-J., eds. (2000) De-Westernizing Media Studies. London: Routledge.

Dean, J. (2009) Democracy and Other Neoliberal Fantasies: Communicative Capitalism and Left Politics. Durham, NC: Duke University Press.

Debray, R. (1996) Media Manifestos: On the Technological Transmission of Cultural Forms, trans. E. Rauth. London: Verso.

Debray, R. (2000) Transmitting Culture, trans. E. Rauth. New York: Columbia University Press.

Debray, R. (2004) God: An Itinerary, trans. J. Mehlmann. London: Verso.

Deleuze, G. and Guattari, F. (1980) Mille plateaux (Capitalisme et Schizophrénie II) [A Thousand Plateaus]. Paris: Editions de Minuit.

deNardis, L. (2009) Protocol Politics: The Globalization of Internet Governance. Cambridge, MA: MIT Press.

Elmer, G. (2004) Profiling Machines: Mapping the Personal Information Economy. Cambridge, MA: MIT Press.

Feilhauer, M. and Zehle, S., eds. (2009) "Ethics of Waste in the Information Society", special issue of International Review of Information Ethics, 11.

Froomkin, A.M. (2003) "Habermas@Discourse.net: Toward a Critical Theory of Cyberspace." Harvard Law Review, 116, 751-873.

Fuchs, C. (2008) Internet and Society: Social Theory and the Information Age. London: Routledge.

Gandy, O.H. Jnr. (1993) The Panoptic Sort: The Political Economy of Personal Information. Boulder, CO: Westview Press.

Gauntlett, D. (2011) Making Is Connecting: The Social Meaning of Creativity, from DIY and Knitting to YouTube and Web 2.0. Cambridge: Polity. 
Gitelman, L. (1999) Scripts, Grooves, and Writing Machines: Representing Technology in the Edison Era. Stanford, CA: Stanford University Press.

Gitelman, L. (2006) Always Already New: Media, History, and the Data of Culture. Cambridge, MA: MIT Press.

Goldsmith, J. and Wu, T. (2008) Who Controls the Internet: Illusions of a Borderless World. Oxford: Oxford University Press.

Gomery, D. (2005) The Coming of Sound: A History. London: Routledge.

Gorz, A. (2010) Ecologica, trans. C. Turner. London: Seagull.

Grau, O. (2003) Virtual Art: From Illusion to Immersion. Cambridge, MA: MIT Press.

Grossman, E. (2007) High Tech Trash: Digital Devices, Hidden Toxics, and Human Health. Washington, DC: Shearwater.

Harvey, D. (1989) The Condition of Postmodernity: An Enquiry into the Origins of Cultural Change. Oxford: Blackwell.

Hassan, R. (2003) The Chronoscopic Society: Globalization, Time and Knowledge in the Networked Economy. New York: Lang.

Hayes, K. and Burge, R. (2003) Coltan Mining in the Democratic Republic of Congo: How Tantalum-Using Industries Can Commit to the Reconstruction of the DRC. Cambridge: Fauna \& Flora International.

Himanen, P. (2001) The Hacker Ethic and the Spirit of the Information Age. New York: Random House.

Holden, J. and Kelty, C. (2005) "The Environmental Impact of the Manufacturing of Seminconductors”. Connections. http://cnx.org/content/m14503/latest.

Huhtamo, E. (2005) "Slots of Fun, Slots of Trouble. Toward an Archaeology of Electronic Gaming" in J. Raessens and J. Goldstein, eds., Handbook of Computer Games Studies. Cambridge, MA: MIT Press, pp. 1-21.

Huhtamo, E. (2006) "Twin-Touch-Test-Redux: Media Archaeological Approach to Art, Interactivity, and Tactility" in O. Grau, ed., MediaArtHistories. Cambridge, MA: MIT Press, pp. 71-101.

Huhtamo, E. (2007) “The Urban Spirograph, or an Archaeology of a Loser”. Paper presented at the FIAF Congress 2007, Tokyo, Japan (April 7-12).

Jenkins, H. (2008) Convergence Culture: Where Old and New Media Collide, rev. edn. New York: New York University Press.

Jones, S.G., ed. (1999) Doing Internet Research: Critical Issues and Methods for Examining the Net. London: Sage.

Kelty, C.M. (2008) Two Bits: The Cultural Significance of Free Software. Durham, NC: Duke University Press.

Kidder, T. (1981) The Soul of a New Machine. Harmondsworth: Penguin.

Kittler, F.A. (1997) Literature, Media, Information Systems: Essays, ed. J. Johnston. Amsterdam: G+B Arts International.

Kittler, F.A. (1999) Gramophone, Film, Typewriter, trans. G. Winthrop-Young and M. Wutz. Stanford, CA: Stanford University Press.

Kittler, F.A. (2010) Optical Media: Berlin Lectures 1999, trans. A. Enns. Cambridge: Polity.

Knorr-Cetina, K. and Brügger, U. (2002) “Traders' Engagement with Markets: A Postsocial Relationship.” Theory Culture \& Society 19(5/6), 161-185. 
Lazzarato, M. (1996) "Immaterial Labour", trans. P. Colilli and E. Emery, in M. Hardt and P. Virno, eds., Radical Thought in Italy: A Potential Politics. Minneapolis, MN: University of Minnesota Press, pp. 133-147.

Lessig, L. (2004) Free Culture: How Big Media Uses Technology and the Law to Lock Down Culture and Control Creativity. New York: Penguin.

Lessig, L. (2006) Code v.2: Code and Other Laws of Cyberspace, rev. edn. New York: Basic Books.

Levy, S. (1984) Hackers: Heroes of the Computer Revolution. New York: Anchor Press/ Doubleday.

Lyon, D. (1994) The Electronic Eye: The Rise of Surveillance Society. Cambridge: Polity.

Lyon, D. (2007) Surveillance Studies: An Overview. Cambridge: Polity.

Mackenzie, A. (2008) "Codecs" in M. Fuller, ed., Software Studies: A Lexicon. Cambridge, MA: MIT Press, pp. 48-55.

MacLean, D. (2003) "The Quest for Inclusive Governance of Global ICTs: Lessons from the ITU in the Limits of National Sovereignty." Information Technologies and International Development, 1(1), 1-18.

Manovich, L. (2001) The Language of New Media. Cambridge, MA: MIT Press.

Massumi, B. (2002) Parables for the Virtual: Movement, Affect, Sensation. Durham, NC: Duke University Press.

Mattelart, A. (1994) Mapping World Communication: War, Progress, Culture, trans. S. Emmanuel and J.A. Cohen. Minneapolis, MN: University of Minnesota Press.

Mattelart, A. (1996) The Invention of Communication, trans. S. Emanuel. Minneapolis, MN: University of Minnesota Press.

Mattelart, A. (2000) Networking the World 1794-2000, trans. L. Carey-Liebrecht and J. Cohen. Minneapolis, MN: University of Minnesota Press.

Maxwell R. and Miller, T. (2008) “Creative Industries or Wasteful Ones?” Urban China 33, 122.

McChesney, R.W. (2008) The Political Economy of Media: Enduring Issues, Emerging Dilemmas. New York: Monthly Review Press.

McLuhan, M. (1964) Understanding Media: The Extensions of Man. London: Sphere.

Mitchell, W.J. (1992) The Reconfigured Eye: Visual Truth in the Post-Photographic Era. Cambridge, MA: MIT Press.

Morley, D. (1980) The "Nationwide" Audience. London: BFI.

Morley, D. (2000) Home Territories: Media, Mobility and Identity. London: Routledge.

Morley, D. (2007) Media, Modernity and Technology: The Geography of the New. London: Routledge.

Morley, D. and Robins, K. (1995) Spaces of Identity: Global Media, Electronic Landscapes and Cultural Boundaries. London: Routledge.

Mueller, M.L. (2004) Ruling the Root: Internet Governance and the Taming of Cyberspace. Cambridge, MA: MIT Press.

O'Siochrú, S. and Girard, B. with Mahan, A. (2002) Global Media Governance: A Beginner's Guide. New York: Rowan and Littlefield.

Papadopoulos, D., Stephenson N., and Tsianos, V. (2008) Escape Routes: Control and Subversion in the Twenty-first Century. London: Pluto.

Parikka, J. (2007) Digital Contagions: A Media Archaeology of Computer Viruses. New York: Peter Lang. 
Parikka, J. (2012) What is Media Archaeology? Cambridge: Polity.

Perron, B. and Wolf, M.J.P., eds. (2009) The Video Games Theory Reader 2, 2nd edn. New York: Routledge.

Raunig, G. (2010) A Thousand Machines, trans. A. Derieg. New York: Semiotext(e).

Ritchin, F. (1990) In Our Own Image: The Coming Revolution in Photography. New York: Aperture Foundation.

Robins, K. (2007) “Transnational Cultural Policy and European Cosmopolitanism.” Cultural Politics 3(2), 147-174.

Rodowick, D.N. (2007) The Virtual Life of Film. Cambridge, MA: Harvard University Press.

Sassen, S. (1991) The Global City: New York, London, Tokyo. Princeton, NJ: Princeton University Press.

Sassen, S. (1994) Cities in a Global Economy. Thousand Oaks, CA: Pine Forge.

Scholz, T. and Liu, L.Y. (2011) From Mobile Playgrounds to Sweatshop City, Situated Technologies Pamphlets 7. New York: Architectural League of New York.

Silverstone, R. and Hirsch, E., eds. (1992) Consuming Technologies: Media and Information in Domestic Spaces. London: Routledge.

Smythe, D. (1994) [1977] "Communications: Blindspot of Western Marxism" in T. Guback, ed., Counterclockwise: Perspectives on Communication. Boulder, CO: Westview Press, 266-291.

Sproull, L. and Kiesler, S. (1991) Connections: New Ways of Working in the Networked Organisation. Cambridge, MA: MIT Press.

Stallman, R.M. (2002) Free Software, Free Society: Selected Essays, ed. J. Gay. Boston, MA: GNU Press/Free Software Foundation.

Sterne, J. (2003) The Audible Past: Cultural Origins of Sound Reproduction. Durham, NC: Duke University Press.

Sterne, J. (2006) “The MP3 as Cultural Artifact.” New Media \& Society 8(5), 825-842.

Sterne, J. (2012) MP3: The Meaning of a Format. Durham, NC: Duke University Press.

Sunstein, C. (2007) Republic.com 2.0. Princeton, NJ: Princeton University Press.

Terranova, T. (2006) "Of Sense and Sensibility: Immaterial Labour in Open Systems.” Data Browser 03. www.kurator.org/media/uploads/publications/DB03/Terranova.pdf.

Thompson, E.P. (1963) The Making of the English Working Class. Harmondsworth: Pelican.

Thussu, D.K., ed. (1998) Electronic Empires: Global Media and Local Resistance. London: Arnold.

Thussu, D.K. (2000) International Communication: Continuity and Change. London: Arnold. Tufte, E.R. (2006) The Cognitive Style of PowerPoint, 2nd edn. Cheshire, CT: Graphics Press. Turkle, S. (1984) The Second Self: Computers and the Human Spirit. London: Granada.

Turner, F. (2006) From Counterculture to Cyberculture: Stewart Brand, the Whole Earth Network, and the Rise of Digital Utopianism. Chicago, IL: University of Chicago Press.

Vermorel, J. and Vermorel, F. (1989) Fandemonium. London: Omnibus.

Virilio, P. (1986) Speed and Politics: An Essay in Dromology, trans. M. Polizotti. New York: Semotext(e).

Vismann, C. (2008) Files: Law and Media Technology, trans. G. Winthrop-Young. Stanford, CA: Stanford University Press.

von Hippel, E. (2005) Democratising Innovation. Cambridge, MA: MIT Press.

Williams, R. (1958) Culture and Society 1780-1950. Harmondsworth: Penguin.

Williams, R. (1961) The Long Revolution. Harmondsworth: Penguin. 
Wolf, M.J.P and Perron, B., eds. (2003) The Video Games Theory Reader. New York: Routledge.

Wombell, P., ed. (1991) Photovideo: Photography in the Age of the Computer. London: Rivers Oram Press.

Zielinski, S. (1999) Audiovisions: Cinema and Television as Entr'actes in History. Amsterdam: Amsterdam University Press.

Zielinski, S. (2006) Deep Time of the Media: Toward an Archaeology of Hearing and Seeing by Technical Means, trans. G. Custance. Cambridge, MA: MIT Press. 